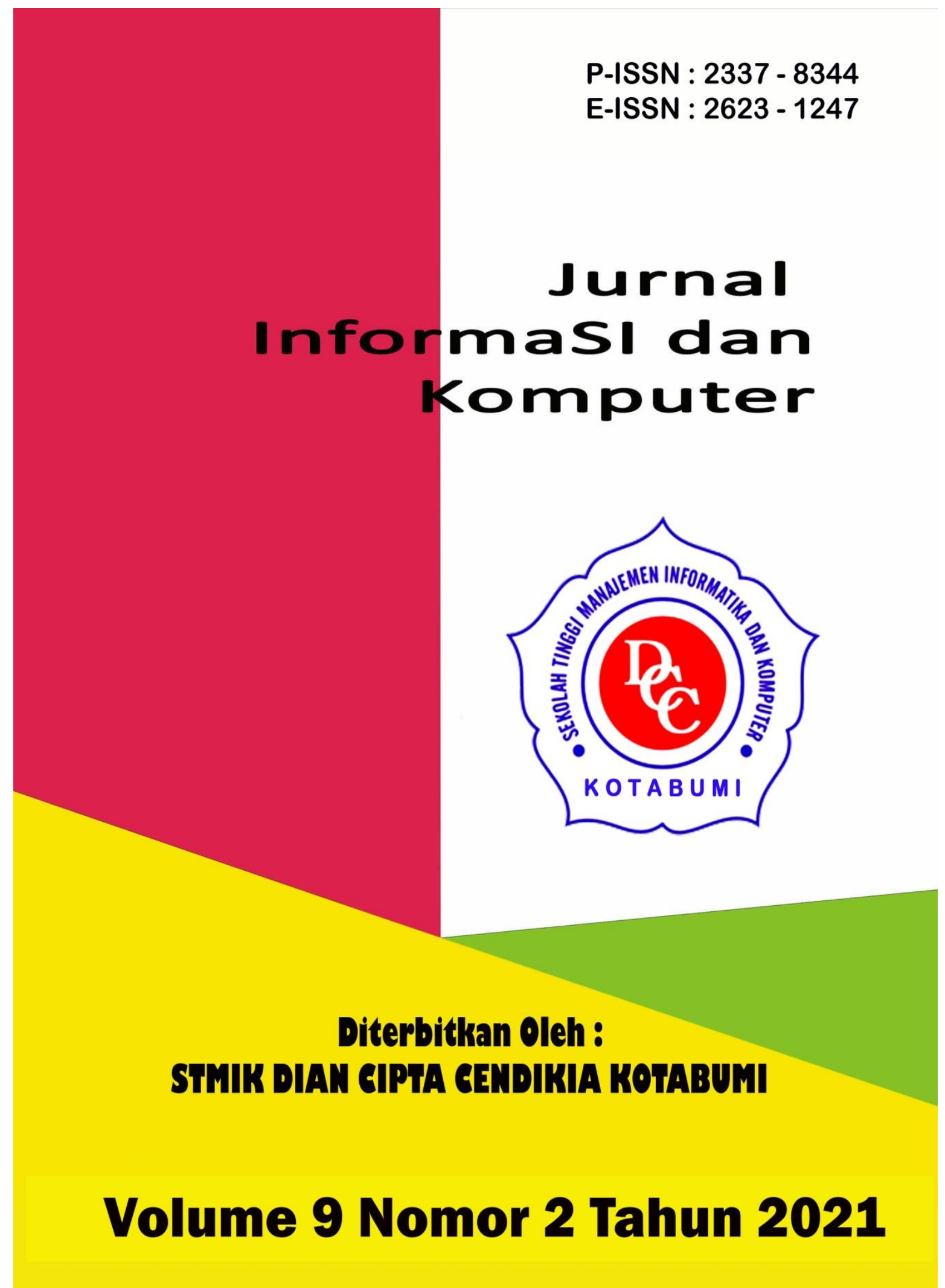




\section{Penerbit}

\section{Lembaga Penelitian STMIK Dian Cipta Cendikia Kotabumi}

Hak atas naskahh/tulisan tetap berada pada penulis, isi diluar tangung jawab penerbit dan Dewan Penyunting 


\section{PENGANTAR REDAKSI}

Puji syukur dipanjatkan kehadirat Tuhan Yang Maha Esa, atas karunia dan limpahan rahmatNYA jualah Jurnal Informasi dan komputer (JIK) STMIK Dian Cipta Cendikia Kotabumi ini dapat terwujud.Jurnal Informasi dan Komputer (JIK) yang terbit dua (2) kali dalam setahun ini merupakan suatu wadah untuk penyebar luasan hasil-hasil penelitian, studi pustaka, karya ilmiah yang berkaitan dengan Informasi dan Komputer khususnya bagi dosen-dosen STMIK Dian Cipta Cendikia Kotabumi serta umumnya para cendikiawan, praktisi, peneliti ilmu Informatika dan Komputer.

Harapan, dengan diterbitkannya Jurnal Informasi dan Komputer (JIK) ini sebagai salah satu bentuk sumbangan pemikiran dalam pengembangan ilmu informatika dan komputer yang berkaitan dengan kajian-kajian di bidang tekhnologi Informatik, Komunikasi Data dan Jaringan Komputer, perancangan dan Rekayasa Perangkat Lunak, serta ilmu-ilmu yang terkait dengan bidang Informasi dan Komputer lainnya.

Berkenaan dengan harapan tersebut, kepada para peneliti, dosen dan praktisi yang memiliki hasil-hasil penelitian, kajian pustaka, karya ilmiah dalam bidang tersebut diatas, dengan bangga redaksi Jurnal Informasi dan Komputer (JIK) menerima naskah ringkasan untuk dimuat pada jurnal Informasi dan Komputer (JIK) STMIK Dian Cipta Cendikia Kotabumi dengan berpedoman pada penulisan naskah jurnal sebagaimana dilampirkan pada halaman belakang (Bagian kulit dalam) buku jurnal ini.

Mutu dari suatu jurnal ilmiah tidak hanya ditentukan oleh para pengelolanya saja, tetapi para penulis dan pembaca jualah yang mempunyai peranan besar dalam meningkatkan mutu jurnal Informatika dan Komputer ini. Merujuk pada realita ini kamu sangat mengharapkan peran aktif dari peneliti untuk bersama-sama menjaga dan memelihara keberlangsungan dari jurnal Informasi dan Komputer STMIK Dian Cipta Cendikia Kotabumi ini. Yang juga tidak kalah pentingnya dari partisipasi tersebut diatas, adalah saran dan kritik yang membangun dari pembaca yang budiman agar kiranya dapat disampaikan langsung kepada redaksi JIK. Saran dan kritik yang membangun akan dijadikan masukan dan pertimbangan yang sangat berarti guna peningkatan mutu dan kualitas Jurnal Informasi dan Komputer STMIK Dian Cipta Cendikia Kotabumi.

Tak lupa diucapkan terima kasih yang tak terhingga atas perhatian dan kerjasama dari semua pihak yang tak dapat disebutkan satu persatu hingga dapat diterbitkan nya Jurnal Informasi dan Komputer (JIK) STMIK Dian Cipta Cendikia Kotabumi. Semoga apa yang telah diperbuat untuk kebaikan akan menjadi amal ibadah, amin.

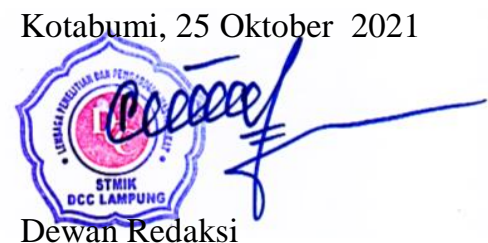




\section{JURNAL INFORMASI DAN KOMPUTER}

Volume 9 Nomor 2 Oktober 2021

Jurnal Informasi dan Komputer merupakan Sarana informasi ilmu pengetahuan, Tekhnologi dan Komunikasi yang berupa hasil penelitian, tulisan ilmiah, Ataupun studi pustaka. Jurnal ini terbit dua kali setahun pada bulan April dan Oktober. Berisi hasil penelitian ilmiah di bidang informatika yang bertujuan untuk menghubungkan adanya kesenjangan antar kemajuan teknologi dan hasil penelitian. Jurnal ini di terbitkan pertama kali pada tahun 2013.

Penanggung Jawab:

Ketua STMIK Dian Cipta Cendikia Kotabumi

\section{Pembina:}

Ketua STMIK Dian Cipta Cendikia Kotabumi Ketua Lembaga Penelitian STMIK Dian Cipta Cendikia Kotabumi

\section{Pimpinan Redaksi}

Dwi Marisa Efendi,.S.Kom.,M.Ti

\section{Redaksi pelaksana}

Rustam,.S.Kom,.M.Ti (STMIK Dian Cipta Cendikia Kotabumi)

Nurmayanti M.Kom (STMIK Dian Cipta Cendikia Kotabumi)

Sukatmi,.S.Kom., M.Kom (AMIK DCC Bandar Lampung)

Sampurna Dadi Riskiono,M.Kom (Universitas Teknokrat Indonesia)

Ifo Wahyu Pratama,S.Kom.,M.Ti(AMIK MASTER Lampung)

\section{Mitra Bestari}

Dr. RZ. ABDUL AZIZ, ST., MT (Institut Informatika dan Bisnis Darmajaya)

Dr. Dadang Sudrajat, S.Si, M.Kom (STMIK IKMI Cirebon)

Dr. Septafiansyah Dwi Putra, S.T., M.T (Politeknik Negeri Lampung)

Dr. Evi Grativiani, S.E., M.S.I (Universitas Sebelas Maret)

Rohmat Indra Borman ( Universitas Teknokrat Indonesia )

Ferry Wongso, S.KOm., M.Kom ( STMIK Darma Pala Riau)

Ferly Ardhy, S.Kom., M.Ti ( Universitas Aisyah Pringsewu )

Firmansyah, S.E., M.Si (STMIK Darma Pala Riau)
Amarudin (Universitas Teknokrat Indonesia)

Didi Susianto, S.T., M.Kom (AMIK Dian Cipta Cendika Bandar Lampung)

Alhibarsyah, St., M.Kom (STMIK Tunas

Bangsa Bandar Lampung)

Kemal Farouq Mauladi, S.Kom .M.Kom (Universitas Islam Lamongan)

Rima Mawarni, M.Kom ( STMIK Dian Cipta Cendikia Kotabumi)

Wira Jaya Hartono, S.Pd., M.Pd ( STMIK Darma Pala Riau)

Penerbit : STMIK Dian Cipta Cendikia Kotabumi Bekerja Sama Dengan LPPM STMIK Dian Cipta Cendikia Kotabumi.

\section{Alamat Redaksi/Penerbit:}

Jl. Negara No. 3 Candimas Kotabumi Lampung Utara

No Telpon/Fax 072423003

Email : 1ppm-stmik@dcc.ac.id 


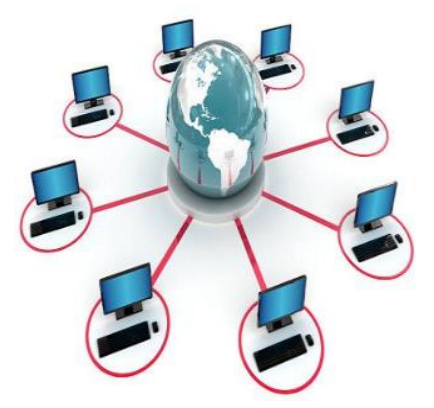

\section{JURNAL INFORMASI DAN KOMPUTER VOL. 9 NO. 2 THN. 2021}

\section{DAFTAR ISI}

Halaman

Sistem Informasi Akuntansi Persedian Barang Berbasis Web Pada Lembaga

Permasyarakatan Kelas II A Banceuy Bandung : "Kelompok Tani Desa Banjar Kertarahayu" Teuku Rian Hardiyansyah, Fatia Salsa Azzahra (Politeknik Piksi Ganesha Bandung ${ }^{1,2}$ ).

Penerapan Finite State Automata Pada Vending Machine Penjual Obat Non Resep

Dokter Dan Keperluan Medis

Eko Supriyanto $^{1}$, Angga Ardiansyah ${ }^{2}$, Frieyadie $^{3}$, Sri Rahayu ${ }^{4}$, Windu Gata ${ }^{5}$

(Universitas Nusa Mandiri ${ }^{12}$ )

Sistem Pendukung Keputusan Untuk Menentukan Kelayakan Pengajuan Sertifikasi Guru Dengan Metode Simple Additive Weighting (Studi Kasus : Ma Al Muhajirin Janti Jogoroto Jombang)

Budiman, umam baharudin, winarti

(Universitas Darul 'Ulum Jombang)

Perancangan Infrastruktur Domain Name Server Lokal Menggunakan Ubuntu Server 16.04

Pada PT. Xyz

Zaenal Mutaqin Subekti, Hendra Setiawan, Satria, Widia Murni Wijaya,

Aliy Hafiz, Warsudi

(STMIK Bani Saleh, Universitas Negeri Yogyakarta, AMIK Dian Cipta Cendikia,

STMIK MIC CIkarang)

Perancangan Sistem Informasi Idea Proposal (Ip) Berbasis Web Pada Pt. Paxel Algorita Unggul

Julian Murhan Sahputra, Indah Purnamasari

(Universitas Nusa Mandiri ${ }^{12}$ )

Sistem Pendukung Keputusan Untuk Menentukan Ekstrakurikuler Atletik

Berdasarkan Bakat Siswa Menggunakan Metode Profile Matching

Agnes Basuki, Petrus Sokibi, Tiara Eka Putri

(Universitas Catur Insan Cendekia)

Penerapan Algoritma K-Means Untuk Pengelompokan Usia Calon Penerima Vaksin

Di Kab. Ngawi

Irna Yuniarfi, Saifulloh

(Universitas PGRI Madiun ${ }^{12}$ )

System Penilaian Seleksi Calon Karyawan Baru Menggunakan Metode Simple Additive Weighting (SAW) Di PT.TNA

Anik Sri Wahyuningsih, Yudhi Firmansyah

(Universitas Panca Sakti Bekasi ) 
Perancangan Sistem Informasi Pembayaran SPP Menggunakan Framework Laravel Ichwan Habib Moudi

(Universitas Panca Sakti Bekasi)

Implementasi Algoritma K-Means Dan Algoritma Apriori Optimasi Kinerja Ecu

(Study Kasus Mobil Avanza Dan Xenia)

Sigit Mintoro' Asep Afandi

(STMIK Dian Cipta Cendikia Kotabumi)

Sistem Pakar Penyakit Buah Kakao Untuk Peningkatan Hasil Panen Kakao Menggunakan

Metode Case Base Reasoning (CBR) Berbasis Web Mobile

Aliy hafiz, Verawati

(AMIK Dian Cipta Cendikia,Bandar Lampung)

Penerapan Metode Rapid Application Develomment (RAD) Dalam Pengembangan

Sistem Pemesanan Menu Berbasis Android

Aris Baihaqi, Tumini

(Fakultas Sains dan Teknologi ${ }^{1,2}$ )

Rancang Bangun Sistem Informasi Geografis Pariwisata Di Lampung Timur

Sukatmi, Rexa Alfa Rizi

(AMIK DCC Bandar Lampung ${ }^{12}$ )

Implementasi Psak No. 45 Pada Proses Penyusunan Laporan Keuangan Menggunakan

M.S. Excel Dan Aplikasi Accurate Accouting Pada STMIK Bani Saleh

Marhakim, Willy Adam

(STMIK Bani Saleh ${ }^{12}$ )

Sistem Prediksi Harga KOPI LAMBAR ( Lampung Barat) Dengan Metode

Backpropagation, dan Double Exponential ( Studi Kasus BUMDES )

Supriyanto, Dwi marisa Efendi,Rhomadhon

(STMIK Dian Cipta cendikia Kotabumi ${ }^{1-}$ )

Sistem Informasi Pemasaran Produk Umkm Berbasis Web Pada Kecamatan Bumi

Nabung Lampung Tengah

Yuli Syafitri, Agus Prasetyo, Reni Astika

(AMIK Dian Cipta Cendikia Bandar Lampung)

Rancang Bangun Aplikasi Pembelajaran Aksara Lampung Berbasis Android

Ferly Ardhy, Hendra Syahrobi

(Universitas Aisyah Pringewu ${ }^{1,}$ STMIK Dian Cipta Cendikia ${ }^{2}$ )

Sistem Pakar Diagnosa Penyakit Kulit Pada Balita Menggunakan Metode Naïve

Bayes Dan Forward Chaining Studi Kasus Puskesmas Cempaka Sungkai Selatan

Sidik Rahmatullah, Rima Mawarni

(STMIK Dian Cipta Cendikia Kotabumi ${ }^{12}$ )

Rekayasa Perangkat Lunak Perhitungan Harga Pokok Produksi Metode

Full Costing Pada Umkm Mitra Cake Di Bandar Lampung

Pitrawati, Arif Sanjaya

(AMIK Dian Cipta Cendikia, Bandar Lampung) 
Rancang Bangun Sistem Ujian Online Menggunakan Algoritma Cosine Similarity

Berbasis Web

Haryono, Zaenal Mutaqin Subekti, Widiyawati, Hidayatullah

(STMIK Bani Saleh ${ }^{1234}$ )

Model Aplikasi Helpdesk Ticketing System Berbasis Web Menggunakan Metode Rad

Indra Permana

Pattern Recognition Tulisan Tangan Huruf Hijaiyah Menggunakan Metode

Convolutional Neural Network (CNN)

Mufassiril Abror, Nopiyanto

(Universitas Panca Sakti Bekasi ${ }^{12}$ )

Aplikasi Sistem Informasi Keuangan Berbasis Android Di Perumahan Taman

Karang Bahagia

Melda Ayulestari

(Universitas Panca Sakti Bekasi)

Audit Pelayanan Sistem Rujukan Online Puskesmas Menggunakan Framework COBIT 5.0

Nurmayanti, Merri Parida, Ngajiyanto, Ina Anzalna

(STMIK Dian Cipta Cendikia Kotabumi ${ }^{1234}$ )

Perancangan Sistem Informasi Pengolahan Data Nilai Siswa Berbasis Web

Erin Ermawati, Anik Sri Wahyuningsih

(Fakultas Sain dan Teknologi, Universitas Panca Sakti Bekasi ${ }^{12}$ )

Pengembangan Sistem Pelaporan Data Hasil Inspeksi Barang Berbasis Web

Siska Putriani

(Universitas Pancasakti Bekasi)

Penerapan Extreme Programming Dalam Perancangan Aplikasi Web Food Market

Tumini, Hilman Septiana

(Fakultas Sains dan Teknologi Universitas Panca Sakti Bekasi ${ }^{1,2}$ )

Sistem Pencarian Barang Berbasis Website Menggunakan Php Dan Mysql

Studi Kasus PT. Surya Technology Industri Sulaeman

(Universitas Panca Sakti Bekasi)

Implementasi Metode Prototype Pada Sistem Peminjaman Alat Kerja Berbasis Web

Di PT SK Metalindo

Ali Mulyanto, Arjun Gunawan

(Univeritas Panca Sakti Bekasi)

Aplikasi Tata Cara Wudhu Menggunakan Teknologi Augmented Reality

Sebagai Media Pembelajaran Di TK Al Fatih

Ahmad Yakub , Idarul Fadli

(Universitas Panca Sakti Bekasi ${ }^{12}$ )

Sistem Pakar Diagnosa Penyakit Ayam Petelur Menggunakan Metode Certainty Factor

Berbasis Web Mochammad

Taufiq Hidayat, Ali Mulyanto

(Universitas Panca Sakti Bekasi ${ }^{12}$ ) 
Penerapan Metode Prototyping Dalam Perhitungan Hasil Produksi Menggunakan

Arduino Uno R3 Dan Php Di PT. Indonesia Epson Industry

Amandha Aulia, Ajar Rohmanu

(Universitas Panca Sakti Bekasi ${ }^{12}$ )

System Pendukung Keputusan Penentuan Guru Teladan Dengan Metode Profile Matching

Hasbulloh, Agmawarnida

(Universitas Panca Sakti Bekasi ${ }^{1,2}$ )

Implementasi Waterfall Method Pada Aplikasi Buku Induk Siswa Berbasis Web

Idam Holid, Yogie Krisnayadi

(Universitas Panca Sakti ${ }^{12}$ )

Pengembangan Text To Speech Media Pembelajaran Untuk Pengenalan

Anggota Tubuh Manusia Kelas V Sekolah Dasar

Juwanda Saputra, Ali Mulianto

(Teknik Infomratika Fakulutas Sains dan Teknologi ${ }^{12}$ )

Perancangan Sistem Peminjaman Barang Berupa Aset Tetap Berbasis Web

Pada Lembaga Permasyarakatan Kelas II A Banceuy Bandung

Guntur Salasa Priambodo, Perwito, Candra Mecca Sufyana

(Politeknik Piksi Ganesha Bandung ${ }^{1,2,3}$ )

Metode Pemilihan Karyawan Terbaik Sebagai Penentu Goodwill Perguruan Tinggi

Dengan Menggunakan Metode Topsis (Studi Kasus Perguruan Tinggi Di Lampung Utara)

Dwi Sartika, Pakarti Riswanto

(STMIK Dian Cipta Cendikia Kotabumi)

Sistem Pendukung Keputusan Pemilihan Merek Smartphone Menggunakan

Metode Analytical Hierarchy Process (AHP)

Ade Kiki Fatmawati, Muhammad Sultan Raflie, Norma Yunita

(Universitas Nusa Mandiri ${ }^{123}$ )

Pattern Recognition Aksara Lampung Menggunakan Algoritma Neural Network

Metode Analytical Hierarchy Process (AHP)

Nopiyanto, Rahmadi

(Universitas Panca Sakti Bekasi) 


\title{
IMPLEMENTASI PSAK NO. 45 PADA PROSES PENYUSUNAN LAPORAN KEUANGAN MENGGUNAKAN M.S. EXCEL DAN APLIKASI ACCURATE ACCOUTING PADA STMIK BANI SALEH
}

\author{
Marhakim $^{1}$, Willy Adam ${ }^{2}$ \\ STMIK Bani Saleh ${ }^{12}$ \\ J1. Mayor M. Hasibuan No. 68 Kota Bekasi \\ E-mail : marhakim.stmikbanisaleh@gmail.com ${ }^{1}$, adamwilly184@gmail.com²
}

\begin{abstract}
ABSTRAK
Penelitian ini bertujuan untuk mengetahui sejauhmana implementasi PSAK No. 45 didalam proses penyusunan Laporan Keuangan STMIK Bani Saleh. Dalam proses penyusunan laporan keuangan STMIK Bani Saleh menggunakan Microsoft Excel dan Paket Aplikasi Akuntansi (Accurate Accounting) sebagai alat bantu, sehingga pekerjaan akuntansi menjadi lebih praktis, cepat dan akurat.

Metodologi yang digunakan metode deskriptif kualitatif dengan langkah-langkah kerja meliputi, pengumpulkan data berupa dokumen dan laporan keuangan STMIK Bani Saleh pada periode akuntansi 2018 dan 2019, identifikasi terhadap proses dan metode penyusunan laporan keuangan STMIK Bani Saleh dibandingkan dengan metode dan proses yang terdapat pada PSAK No. 45 dan mengambil kesimpulan tentang implementasi PSAK No. 45 pada Pelaporan Keuangan STMIK Bani Saleh.

Laporan keuangan STMIK Bani Saleh telah menyelenggarakan pembukuan berbasis akuntansi yang terdiri dari neraca, laporan aktivitas, laporan arus kas, laporan perubahan kekayaan bersih dan laporan aktiva tetap. Penyusunan laporan keuangan STMIK Bani Saleh yang sesuai dengan PSAK No. 45 dan sudah menjadi pedoman, karena termasuk organisasi nirlaba. Laporan keuangan yang berkualitas, mempunyai daya banding sesuai dengan PSAK N0. 45 seharusnya sudah menjadi kebutuhan, tidak lagi menjadi kewajiban atau beban bagi pengelola perguruan tinggi.
\end{abstract}

Kata kunci : Akuntansi, Paket Aplikasi Akuntansi, Laporan Keuangan, Organisasi Nirlaba, PSAK 45

\begin{abstract}
This study aims to determine the extent of the implementation of PSAK No. 45 in the process of preparing the Financial Statements of STMIK Bani Saleh. In the process of preparing financial statements, STMIK Bani Saleh uses Microsoft Excel and the Accounting Application Package (Accurate Accounting) as tools, so that accounting work becomes more practical, fast and accurate.

The methodology used is a qualitative descriptive method with working steps including collecting data in the form of documents and financial reports of STMIK Bani Saleh in the 2018 and 2019 accounting periods, identification of the process and methods of preparing financial statements of STMIK Bani Saleh compared to the methods and processes contained in PSAK No. 45 and draw conclusions about the implementation of PSAK No. 45 on the Financial Reporting of STMIK Bani Saleh.

STMIK Bani Saleh's financial report has maintained accounting-based bookkeeping consisting of a balance sheet, activity report, cash flow report, net worth change report and fixed asset report. Preparation of the financial statements of STMIK Bani Saleh in accordance with PSAK No. 45 and has become a guideline, because it is a non-profit organization. Quality financial reports, have comparability in accordance with PSAK No. 45 should have become a necessity, no longer an obligation or a burden for university administrators.
\end{abstract}

Keywords: Accounting, Accounting Application Package, Financial Statements, Non-Profit Organizations, PSAK 45

109 |S T M I D i a n C ipta Cendikia Kotabu m i 


\section{PENDAHULUAN}

Akuntansi adalah bahasanya bisnis (Accounting is Bussiness Language), dengan akuntansi suatu entitas bisa menyampaikan informasi terkait dengan kondisi keuangan kepada pihak-pihak yang berkepentingan. Kondisi keuangan yang dimaksud terdiri dari jumlah harta, utang dan modal pada saat tertentu, serta kegiatan atau aktivitas selama satu periode akuntansi yang mencerminkan prestasi dengan membandingkan jumlah pendapatan dengan beban pada periode tertentu. Informasi tersebut disajikan dalam bentuk laporan keuangan yang dikenal dengan istilah neraca (Balance Sheet) dan Laporan Laba Rugi (Profit \& Loss Statement).

Selain itu dari akuntansi juga memberikan informasi tentang perkembangan modal dari satu periode ke periode berikutnya. Jumlah laba akan menambah modal, sedangkan jumlah kerugian akan mengurangi modal. Perubahan modal atau sering juga disebut dengan kekayaan bersih akan terlihat pada Laporan Perubahan Madal atau Laporan Perubahan Kekayaan Bersih (Capital Statament). Kemudian yang tidak kalah pentingnya adalah bagaimana suatu entitas mengatur aliran kas masuk dan kas keluar supaya tidak terjadi defisit, hal ini bisa dilihat dari Laporan Arus Kas (Cash Flow Statement).

Pada Perguruan Tinggi, laporan keuangan yang disebutkan diatas, bukan lagi menjadi kewajiban semata, melainkan sudah menjadi kebutuhan terutama sebagai dasar dalam pengambilan berbagai keputusan. Demikian halnya dengan STMIK Bani Saleh sebagai Unit Pelaksana Teknis (UPT) atau amal usaha Yayasan Bani Saleh membutuhkan informasi-informasi tersebut. Untuk itu STMIK Bani Saleh sesuai dengan instruksi dari Pengurus Yayasan Bani Saleh mulai tahun 2018 harus menyusun laporan keuangan dengan menyelenggarakan akuntansi berdasarkan Pernyataan Standar Akuntansi Keuangan No. 45 yang disingkat dengan PSAK 45. Untuk mempermudah proses akuntansi, STMIK Bani Saleh menggunakan Microsoft Excel dan Paket Aplikasi Akuntansi (Accurate Accounting) sebagai alat bantu, sehingga laporan keuangan dapat disusun dan disajikan dengan lebih praktis, lebih cepat dan lebih akurat.
Tujuan utama laporan keuangan nirlaba adalah menyediakan informasi yang relevan untuk memenuhi kepentingan para penyumbang, penyelenggara, pengelola, kreditur, dan pihak lain yang menyediakan sumber pendanaan.

Penelitian ini membahas bagaimana implementasi akuntansi berdasarkan PSAK 45 menggunakan Microsoft Excel dan Paket Aplikasi Akuntansi (Accurate Accounting) pada Perguruan Tinggi, sebagai studi kasus peneliti memilih STMIK Bani Saleh sebagai tempat penelitian dengan harapan dapat menambah khasanah pengetahuan tentang laporan keuangan Perguruan Tinggi yang diselenggarakan oleh organisasi nirlaba, khususnya bagi civitas akademika Sekolah Tinggi yang berada dibawah naungan Yayasan Bani Saleh dan masyarakat pada umumnya. Tujuan dari penelitian ini adalah untuk mengetahui apakah implementasi proses akuntansi dan pelaporan keuangan tahun 2018 dan 2019 pada STMIK Bani Saleh dengan menggunakan Paket Aplikasi Akuntansi (Accurate Accounting) telah sesuai dengan apa yang tercantum pada PSAK 45

\section{METODE PENELITIAN}

Pembahasan yang akan dilakukan pada penelitian ini adalah mempelajari laporan keuangan STMIK Bani Saleh tahun terakhir (Tahun 2018 dan 2019) dengan metode deskriptif kualitatif dengan langkah-langkah sebagai berikut:

a. Mengumpulkan data berupa dokumen dan laporan keuangan STMIK Bani Saleh tahun 2018 dan 2019

b. Melakukan identifikasi terhadap metode penyusunan laporan keuangan STMIK Bani Saleh tahun 2018 dan 2019 yang menggunakan Microsoft Excel dan Paket Aplikasi Akuntansi dibandingkan dengan metode yang terdapat pada PSAK 45

c. Melakukan evaluasi terhadap implementasi PSAK No. 45 pada proses dan laporan keuangan STMIK Bani Saleh

d. Mengambil kesimpulan tentang implementasi PSAK 45 pada Pelaporan Keuangan STMIK Bani Saleh

Langkah-langkah tersebut digambarkan sebagai berikut: 
a. Pengumpulan data

b. Melakukan identifikasi data

c. Evaluasi Implementasi PSAK No. 45

d. Mengambil Kesimpulan

Data yang digunakan dalam penelitian ini berupa data primer yang diperoleh di STMIK Bani Saleh berupa Bukti Penerimaan Kas/Surat Perintah Menerima Uang (SPMU), Bukti Pengeluaran Kas/Surat Perintah Membayar (SPM), Buku harian, dan Laporan Keuangan.

Teknik pengumpulan data yang dilakukan adalah:

\section{a. Survey}

Pengumpulan data dilakukan dengan melakukan pengamatan langsung dilapangan.

b. Wawancara

Wawancara atau tanya jawab secara lisan dengan unit yang terkait.

\section{b. Dokumentasi}

Teknis pengumpulan data yang dilakukan mencari dan mengumpulkan data yang diperlukan. Pengumpulan dan Identifikasi data dilakukan oleh anggota peneliti, sedangkan evaluasi dan pengambilan kesimpulan dilakukan oleh Ketua Peneliti.

\section{HASIL DAN PEMBAHASAN}

\subsection{Langkah-Langkah Penyusunan Laporan Keuangan STMIK Bani Saleh}

STMIK Bani Saleh sebagai Unit Usaha Yayasan Bani Saleh mulai tahun 2018 dan 2019 sudah menyelenggarakan akuntansi dalam penyusunan laporan keuangan. Langkah-langkah yang dilakukan untuk menghasilkan laporan keuangan adalah sebagai berikut:

\section{a. Pembuatan Dokumen Sumber}

Setiap transaksi yang terjadi di STMIK Bani Saleh direkam sebagai bukti yang dapat dipertanggungjawabkan sebagai sumber pencatatan ke buku harian dan jurnal. Pembuatan Dokumen sumber dilakukan secara manual menggunakan MS. Excell. Dokumen sumber tersebut terdiri dari:

\section{Surat Perintah Menerima Uang (SPMU)}

Surat Perintah Menerima Uang adalah dokumen yang digunakan untuk merekam transaksi penerimaan uang atau Bukti Kas Masuk (BKM) yang dilengkapi dengan bukti-bukti Pendukung. SPMU ditandatangani oleh Ketua STMIK dan Wakil Ketua 2 setelah di paraf oleh Petugas Keuangan.

\section{Surat Perintah Membayar (SPM)}

Surat Perintah Membayar adalah dokumen yang digunakan untuk merekam transaksi pengeluaran kas/bank atau Bukti Kas Keluar (BKK) yang dilengkapi dengan bukti-bukti pendukung. SPM ditandatangani oleh Wakil Ketua 2 dan Ketua dan Pihak yang menerima uang setelah diverifikasi dan diparaf oleh Petugas Keuangan. Pada umumnya Kasir /Baian Keuangan melakukan pembayaran setelah ditandatangani oleh Wakil Ketua 2 dan Ketua, kecuali pembayaran yang sifatnya rutin dan jumlahnya sudah pasti.

\section{Memo Dinas/Nota Dinas}

Memo Dinas/Nota Dinas adalah dokumen yang digunakan untuk merekam transaksi selain pengeluaran dan penerimaan kas, biasanya untuk transaksi yang terkait dengan jurnak koreksi atau jurnal penyesuaian yang ditandatangani oleh Ketua atau Wakil Ketua 2 yang dilengkapi dengan bukti pendukung. Memo Dinas/Nota Dinas ini secara umum dikenal dengan istilah Bukti Memorial.

\section{b.Pencatatan Dokumen Sumber ke Kas di} Bank, Buku Kas Harian dan Kas Kecil.

STMIK Bani Saleh menyelenggaran akuntansi secara dengan metode cash basis dan accrual basis. Berdasarkan Cash Basis dokumen sumber yang terdiri dari SPM, SPMU dan Memo Dinas/Nota Dinas yang terkait dengan kas dicatat pos atau rekening yang sesuai. Rekening kas yang digunakan untuk memcatat transaksi terdiri dari:

\section{Kas di Bank}

Setiap penerimaan uang kuliah dari mahasiswa yang terdiri dari SPP, BPP dan SKS diterima lewat bank. Tujuan penerimaa uang kuliah lewat bank adalah untuk mengurangi pekerjaa teknis di unit keuangan, dan untuk pengendalian terhadap keuangan STMIK Bani Saleh. 


\section{Kas Harian}

Kas harian adalah dana yang disiapkan untuk membiayai kegiatan operasional (kegiatan tridharma dan biaya personil) berasal dari dana yang diajukan ke Pengurus Yayasan setiap bulannya. STMIK menerima dropping dana dari Pengurus Yayasan, dana tersebut berasal dari dana yang tersimpan di Rekening Bank.

\section{Kas Kecil}

Kas kecil adalah dana yang disiapkan untuk membayar pengeluaran rutin yang jumlahnya relatif kecil, dengan menggunakan sisten dana tetap. Kas Kecil diganti setiap minggu sebesar jumlah yang telah digunakan, sehingga saldo kas kecil tetap sebesar saldo sebelumnya.

Berdasarkan accrual basis, setiap tunggakan mahasiswa setiap akhir semester dicatat sebagai Piutang Mahasiswa dan diakui sebagai pendapatan pada periode tersebut, walaupun penerimaan kas nya pada periode berikutnya. Selain itu juga mulai tahun 2018 dan 2019 setiap pembelian aktiva tetap dicatat sebagai aktiva tetap yang disusutkan setiap periode dengan metode garis lurus. Kegiatan pencatatan kas dibank, kas harian dan kas kecil dibuat secara manual menggunakan MS Excell.

\section{c. Pencatatan Dokumen Sumber Ke Jurnal}

Dokumen sumber yang terdiri dari SPMU, SPM dan Memo Dinas/Nota Dinas, secara kronologis diinput ke Aplikasi Accurate Accounting yang menghsilkan jurnal. Jurnal yang dibuat oleh Staf Akuntansi STMIK Bani Saleh terdiri dari:

\section{Jurnal Penerimaan Kas}

Jurnal Penerimaan Kas merupakan catatan atas penerimaan kas yang bersumber dari segala sumber, terutama dari penerimaan uang kuliah dari mahasiswa yang diinput pada Aplikasi Accurate Modul Cash/Bank sebagai penerimaan. Jurnal penerimaan kas bersumber dari SPMU, jurnal yang dibuat adalah sebagai berikut:

(D) Kas di Bank Rp.xxxxx

(K) Penerimaan Uang Kuliah (SPP, BPP, SKS) Rp. Xxxxx

\section{Jurnal Pengeluaran Kas}

Untuk mendanai kegiatan operasional disediakan dana Kas Harian sesuai dengan permintaan dari Bagian Keuanga yang input pada Aplikasi Accurate modul cash/bank sebagai penerimaan. Jurnal ini bersumber dari SPMU untuk mengisi kas harian adalah:

(D) Kas Harian

Rp. $x x x x$

(K) Kas di Bank)

$$
\text { Rp. Xxxxx }
$$

Jurnal Pengeluaran Kas merupakan catatan atas pengeluaran kas untuk membiayai seluruh kegiatan operasional institusi yang diinput ke Aplikasi Accurate modul Cash/Bank sebagai pembayaran. Jurnal pengeluaran kas bersumber dari SPM yang di, jurnal yang dibuat adalah sebagai berikut:

(D) Biaya (sesuai dengan jenis biaya) Rp. xxxxx

(K) Kas Harian $\mathrm{Xxxxx}$

Rp.

\section{Jurnal Umum}

Jurnal Umum merupakan catatan atas transaksi yang tidak terkait dengan penerimaan dan pengeluaran kas yang dibuat berdasarkan Memo Dinas/Nota Dinas diinput pada Aplikasi Accurate modul General Ledger sebagai jurnal voucher. Contoh jurnal penyusutan:

(D) Biaya Penyusutan Peralatan Kantor Rp. Xxxxx

(K) Akumulasi Penyusutan Peralatan Kantor) Rp. $x x x x x$

\section{d. Posting Jurnal Ke Buku Besar dan Neraca Saldo}

Posting jurnal ke buku besar merupakan proses memindahkan jurnal ke buku besar yang sesuai secara kronologis/berurutan. Kegiatan memindahkan jurnal ke buku besar di STMIK Bani Saleh. Buku Besar merupakan buku tempat melakukan perhitungan saldo rekening pada saat tertentu. Saldo dari masing-masing buku besar dilaporkan atau diringkas setiap akhir bulan pada suatu daftar yang disebut dengan Neraca Saldo. Dengan menggunakan Aplikasi Accurate Accounting, proses posting jurnal ke buku besar dan pembuatan neraca saldo dilakukan secara komputerisasi.

\section{e. Jurnal Penyesuaian}

Jurnal Penyesuaian dibuat oleh Staf Akuntansi STMIK Bani Saleh pada tanggal 31 Desember 
2018 dan 2019 untuk mencatat penyusutan aktiva tetap. Semua aktiva tetap disusutkan kecuali tanah dan Bangunan, karena tanah dan bangunan dikelola oleh Pengurus Yayasan. Aktiva Tetap yang disusutkan adalah: Kendaraan, Inventaris Kantor, Inventaris Kelas, Inventaris Laboratorium, Inventaris Pusat Komunikasi (Puskom), Inventaris Perpustakaan, dan Inventaris Bagian Umum/Rumah Tangga. Jurnal penyesuaian diinput ke Aplikasi Accurate sebagai jurnal voucher.

\section{f. Penyusunan Neraca Saldo Setelah Disesuaikan}

Untuk menyusun Laporan Keuangan tahun 2018 dan 2019 terlebih dahulu harus menyiapkan Neraca Saldo Disesuaikan Per 31 Desember 2018 dan 2019 (akhir periode). Neraca saldo tersebut disusun dengan kolom sebagai berikut: No. Akun, Nama Akun, Saldo Awal D dan K, Mutasi D dan K, Saldo Akhir D dan K. Angka yang dilaporkan pada laporan keuangan adalah angka-angka yang terdapat pada kolom Saldo Akhir D dan K. Pembuatan neraca saldo ini menggunakan aplikasi accurate yang dilakukan secara komputerisasi.

\section{g. Penyusunan Laporan Keuangan}

Penyusunan Laporan Keuangan STMIK Bani Saleh terdiri dari tahapan berikut ini:

\section{Laporan Laba Rugi}

Untuk melihat kinerja keuangan dalam satu periode STMIK Bani Saleh menyusun Laporan Laba Rugi Standar dari Januari sampai dengan Desember 2018 dan 2019. Laporan Laba Rugi tersebut menggambarkan jumlah pendapatan dan biaya operasional dalam satu tahun, serta saldo surplus atau saldo minus. Pendapatan yang diperoleh berasal dari mahasiswa terdiri dari Sumbangan Pembangunan Pendidikan (SPP), Biaya Pembinaan Pendidikan (BPP) dan Satuan Kredit Semester (SKS). Selain dari mahasiswa STMIK juga menerima pendapatan lain-lain dari kegiatan pelayanan teknis melalaui kegiatan pengabdian kepada masyarakat dan hibah.

\section{Neraca}

Neraca STMIK Bani Saleh disusun dalam bentuk skontro yang terdiri dari Aktiva,
Kewajiban dan Ekuitas. Aktiva dikelompokkan menjadi duan bagian yabg terdiri dari aktiva lancar dan aktiva tetap. Kewajiban juga demikian terdiri dari kewajiban lancar dan kewajiban jangka panjang, namun selama tahun 2018 ini STMIK Bani Saleh tidak mempunyai kewajiban jangka panjang. Untuk ekuitas terdiri dari Kekayaan Bersih Terikat Temporer dan Kekayaan Bersih Terikat Permanen dan Kekayaan Bersih Tidak Terikat. Selama tahun 2018 tidak terdapat Kekayaan Bersih Terikat, sehingga yang terdapat pada neraca hanya Aktiva Bersih Tidak Terikat.

\section{Laporan Perubahan Kekayaan Bersih}

Laporan Perubahan Kekayaan Bersih STMIK Bani Saleh menggambarkan saldo awal Kekayaan Bersih Terikat dan Kekayaan Bersih Tidak Terikat pada awal periode(1 Januari 2018) ditambah dengan Surplus dari Laporan Laba Rugi atau dikurangi dengan saldo minus dari Laporan Laba Rugi, serta saldo kekayaan bersih pada akhir periode akuntansi (31 Desember 2018). Pada Tahun 2018 seluruh ekuitas merupakan Kekayaan Bersih Tidak Terikat.

\section{Laporan Arus Kas}

Laporan Arus Kas STMIK Bani Saleh disusun menggunakan metode langsung yang terdiri dari tiga bagian, yaitu arus kas aktivitas operasional, arus kas aktivitas investasi dan arus kas aktivitas pendanaan. Aruskas aktivitas operasional merupakan arus kas yang berasal dari kegiatan pokok yang bersumber dari mahasiswa dikurangi dengan biaya operasional selama satu tahun. Pada tahun 2018 arus kas aktivitas operasional mempunyai saldo arus kas yang surplus. Arus kas investasi tahun 2018 bersaldo minus karena dalam tahun 2018 sedang STMIK Bani Saleh melakukan investasi dalam meningkatkan sarana berupa investasi Peralatan Laboratorium, Peralatan kelas, Peralatan Kantor, Peralatan Perpustakaan dan Pealatan Pusat Komunikasi (Puskom). Arus kas aktivitas pendanaan juga surplus yang bersumber dari kenaikan aktiva bersih dalam tahin 2018. Secara keseluruhan arus kas tahun 2018 adalah minus atau mengalami penurunan saldo Kas/Bank, karena Kas/Bank digunakan untuk investasi.

\section{Ringkasan Daftar Aktiva Tetap dan Catatan Atas Laporan Keuangan}


Selain laporan keuangan yang utama diatas, STMIK Bani Saleh juga menyusun Laporan tentang aktiva tetap dalam laporan yang disebut dengan Ringkasan Daftar Aktiva Tetap. Ringkasan Daftar Aktiva Tetap ini sangat berguna sekali dalam pengelolaan aktiva tetap meliputi pembelian aktiva tetap, pemeliharaan dan penyusutan aktiva tetap, serta penghapusan aktiva tetap. Untuk memberikan informasi yang lebih terperinci, beberapa pos yang terdapat pada laporan keuangan dilengkapi dengan penjelasan pada Catatan atas Laporan Keuangan.

Semua laporan keuangan tersebut diatas dibuat secara komputerisasi sesuai dengan periode yang diinginkan (bulanan, triwulan, semester dan tahunan) menggunakan aplikasi accurate accounting.

\subsection{Perbandingan Proses Akuntansi dan Penyusunan Laporan Keuangan STMIK Bani Saleh Dengan PSAK 45}

Berikut ini perbandingan antara proses akuntansi dan penyusunan laporan keuangan STMIK Bani Saleh dengan PSAK 45. Perbandingan tersebut dikelompokkan dalam dua hal berikut ini:

\section{a. Proses Akuntansi (tahap pencatata dan pengikhtisaran)}

Proses akuntansi dikenal dengan tahap pencatatan yang terdiri dari pembuatan Dokumen Sumber, Pencatatan Buku Harian/Jurnal dan Posting Ke Buku Besar dan tahap pengikhtisaran yang terdiri dari penyusunan Neraca Percobaan, pembuatan Jurnal Penyesuaian, dan Penyusunan Neraca Saldo. Setiap transaksi keuangan yang terjadi dilengkapi dengan dokumen sumber serta dokumen pendukung untuk menjamin kesahihan transaksi. Transaksi dikelompokan dalam tiga kategori yaitu transaksi penerimaan kas yang dibuktikan dengan SPMU, transaksi pengeluaran kas yang dibuktikan dengan SPM, dan transaksi umum yang dibuktikan dengan Bukti Memorial. Dokumen sumber tersebut digunakan sebagai dasar untuk pembuatan buku harian/jurnal dengan menentukan rekening yang di debet dan rekening yang di kredit. Jurnal yang dibuat meliputi Jurnal Penerimaan Kas, Jurnal Pengeluaran Kas, dan Jurnal Umum. Secara periodik jurnal-jurnal tersebut dipindahkan ke buku besar yang sesuai. Pada setiap akhir periode berdasarkan saldo buku besar disusun Neraca Percobaan sekalian untuk mengecek keseimbangan jumah saldo debet dan kredit. Untuk menentukan saldo yang benar dari beberapa rekening dan untuk mencatatat penyusutan aktiva tetap pada akhir periode dibuat jurnal penyesuaian. Jurnal Penyesuaian di pindahkan ke buku besar yang sesuai sehingga menghasilkan Neraca Saldo sebagai dasar untuk menyusun Laporan Keuangan. Semua kegiatan mulai dari pembuatan dokumen sumber, pencatatan buku harian/jurnal dan posting ke buku besar, penyusunan Neraca Percobaan, Jurnal Penyesuaian dan Neraca Saldo di STMIK Bani Saleh telah sesuai dengan prinsip akuntansi yang berlaku umum dan sesuai dengan PSAK 45.

\section{b. Tahap Penyusunan Laporan Keuangan}

Perbandingan laporan keuangan STMIK Bani Saleh dengan Laporan Keuangan menurut PSAK 45, meliputi:

\section{Laporan Laba Rugi}

Isi laporan laba rugi yang dibuat oleh STMIK Bani Saleh pada umumnya sama dengan Laporan Aktivitas pada PSAK 45 yang merupakan perhitungan selisih antara jumlah pedapatan yang diterima dan jumlah biaya yang dikeluarkan selama satu tahun, namun terdapat perbedaan berikut ini:

a. STMIK Bani Saleh memakai istilah Laporan Laba Rugi, sedangkan menurut PSAK 45 menggunakan istilah Laporan Aktivitas.

b. Selisih antara pendapatan dengan biaya pada Laporan Laba Rugi STMIK Bani Saleh disebut dengan Laba (Rugi) Bersih, sedangkan menurut PSAK 45 disebut dengan Kenaikan (Penurunan) Kekayaan Bersih atau Saldo Surplus atau Minus.

\section{Laporan Posisi Keuangan (Neraca)}

Laporan Posisi Keuangan (Neraca) STMIK Bani Saleh dan Laporan Posisi Keuangan (Neraca) menurut PSAK 45 sama-sama berisi tentang Aktiva, Kewajiban dan Kekayaan Bersih. Pengelompokan Aktiva dan Kewajiban pada Neraca STMIK Bani Saleh telah sesuai dengan PSAK 45. Perbedaan hanya pada penyajian Kekayaan Bersih, STMIK Bani Saleh menyajikan Kekayaan Bersih Tidak Terikat. 
Sedangkan pada PSAK 45 membedakan Kekayaan Bersih menjadi tiga bagian yaitu: Kekayaan Bersih Tidak terikat, Kekayaan Bersih Terikat Temporer, dan Kekayaan Bersih Terikat Permanen.

\section{3..Laporan Perubahan Kekayaan Bersih}

Laporan Kekayaan Bersih STMIK Bani Saleh menggambarkan saldo Kekayaan Bersih awal periode, Kenaikan (Penurunan) Kekayaan Bersih, dan saldo Kekayaan Bersih pada akhir periode. Pada Laporan Perubahan Kekayaan Bersih Bani Saleh belum mengelompokkan Kekayaan Bersih Tidak Terikat, Kekayaan Bersih Terikat Temporer, dan Kekayaan Bersih Terikat Permanen.

\section{Laporan Arus Kas}

Laporan Arus Kas yang disusun oleh STMIK Bani Saleh menggunakan metode langsung dengan mengelompokkan arus kas kedalam tiga kelompok yaitu, arus kas aktivitas operasional, arus kas aktivitas investasi dan arus kas aktivitas pendanaan. Laporan Arus Kas yang dibuat oleh STMIK Bani Saleh telah sesuai dengan Laporan Arus Kas pada PSAK 45.

\section{Ringkasan Aktiva Tetap dan Catatan Atas Laporan Keuangan}

Ringkasan Aktiva Tetap merupakan laporan pendukung untuk memberikan informasi tentang aktiva tetap yang dimiliki oleh STMIK Bani Saleh. Namun demikian STMIK Bani Saleh belum melengkapi laporan keuangannya dengan beberapa penjelasan yang lebih lengkap yang dihimpun pada Catatan Atas Laporan Keuangan.

\section{KESIMPULAN}

\subsection{Kesimpulan}

Dengan memperhatikan pembahasan pada bab IV diatas, dapat disimpulkan sebagai berikut:

a. STMIK Bani Saleh menyelengarakan proses akuntansi dikelompokkan dalam dua tahap yaitu tahap pencatatan dan pengikhtisaran. Tahap pencatatan yang terdiri dari pembuatan Dokumen Sumber (SPMU, SPM dan Memo Dinas/Nota
Dinas), Pencatatan Buku Harian (menggunakan MS. Excell) dan input jurnal (menggunakan aplikasi accurate). Tahap pengikhtisaran terdiri dari Posting Ke Buku Besar, penyusunan Neraca Percobaan, pembuatan Jurnal Penyesuaian, dan Penyusunan Neraca Saldo (menggunakan aplikasi accurate accounting). Semua tahapan tersebut sudah sesuai dengan siklus akuntansi yang berlaku umum dan sudah sesuai dengan PSAK 45.

b. Laporan Keuangan STMIK Bani Saleh Tahun 2018 dan 2019 terdiri dari: Laporan Laba Rugi, laporan Posisi Keuangan (Neraca), Laporan Perubahan Kekayaan bersih, Laporan Arus Kas, dan Ringkasan Daftar Aktiva Tetap dan. Dari kelima laporan keuangan tersebut ada beberapa hal yang belum sesuai dengan PSAK 45, yaitu Laporan Laba Rugi, Neraca dan Catatan Atas Laporan Keuangan.

c. STMIK Bani Saleh menggunakan judul Laporan Laba Rugi, sedangkan menurut PSAK 45 adalah Laporan Aktivitas, dan selisih antara pendapatan dan biaya disebut dengan Laba bersih, sedangkan menurut PSAK 45 adalah Saldo Surplus atau Kenaikan Kekayaan/Asset Bersih.

d. Pada Neraca STMIK Bani Saleh belum memisahkan antara Kekayaan Bersih Terikat dan Tidak Terikat, sedangkan menurut PSAK 45 Kekayaan Bersih dikelompokkan menjadi Kekayaan Bersih Tidak Terikat, Kekayaan Bersih Terikat Temporer dan kekayaan Bersih Permanen.

e. STMIK Bani Saleh sudah membuat Ringkasan Daftar Aktiva Tetap untuk mengelolan Pengadaan Aktiva Tetap, Pemeliharaan Aktiva Tetap dan Penghapusan Aktiva Tetap, namu belum membuat Catatan Atas Laporan Keuangan seperti yang terdapat pada PSAK 45.

\subsection{SARAN}

Supaya implementasi PSAK 45 di STMIK Bani Saleh, khususnya dalam hal penyelenggaraan akuntansi supaya menjadi lebih baik, kami menyarankan beberapa hal berikut ini: 
a. Untuk merekam transaksi-transaksi yang tidak terkait dengan penerimaan dan pengeluaran kas disarankan untuk menyediakan dokumen sumber yang formal berupa Bukti Memorial sebagai pelengkap dari Memo Dinas/Nota Dinas dari Pimpinan.

b. Laporan Laba Rugi STMIK Bani Saleh disarankan untuk diganti dengan Laporan Aktivitas, dan selisih antara pendapatan dan biaya juga diganti dari Laba Bersih menjadi Kenaikan Kekayaan Bersih atau Saldo Surplus. Apabila Rugi meggunakan istilah Penurunan Kekayaan Bersih atau Minus

c. Pada Laporan Posisi Keuangan (Neraca) STMIK Bani Saleh sebaiknya membedakan Kekayaan Bersih Tidak Terikat, Kekayaan Bersih Terikat Temporer, dan Kekayaan Bersih Terikat Permanen

d. Untuk memberikan penjelasan secara lebih terperinci tentang suatu pos tertentu, Laporan Keuangan STMIK Bani Saleh sebaiknya dilengkapi dengan Catatan Atas Laporan Keuangan.

\section{DAFTAR PUSTAKA}

[1] Bastian, Indra, Akuntansi Yayasan dan Lembaga Publik, Penerbit Erlangga, Jakarta, 2007

[2] Undang-Undang Republik Indonesia Nomor 16 Tahun 2001 Tentang Yayasan, 2001
[3] Mardiasmo, Perpajakan Edisi Revisi 2009, Penerbit Andi Yogyakarta, Yogyakarta, 2008

[4] Soemarso, S.R., Akuntansi Suatu Pengantar, Penerbit Salemba Empat. Jakarta, 2002

[5] Mulyadi, Sistem Akuntansi, Penerbit Salemba Empat, Jakarta, 2008

[6] PT Cipta Piranti Sejahtera, Buku Manu (Manual Book) Accurate Accounting Software Versi 5

[7] Ikatan Akuntan Indonesia (IAI), Pernyataan Standar Akuntansi Keuangan (PSAK) No. 45, Penerbit Salemba Empat, Jakarta, 2015

[8] James A. Hall, Sistem Informasi Akuntansi, Penerbit Salemba Empat, Jakarta, 2001

[9] Yusuf Al Haryono, Dasar-Dasar Akuntansi Jilid , STIE YKPN Yogyakarta, 2001

[10] Yusuf Al Haryono, Dasar-Dasar Akuntansi Jilid 2, STIE YKPN, Yogyakarta, 2001

Ucapan Terima Kasih Kepada:

Ketua LLDIKTI Wilayah IV Jabar dan Banten yang telah mendanai Penelitian Dosen Pemula (PDP) Tahun 2019, sehingga kami bisa menghasilkan luaran penelitian berupa Jurnal Ilmiah ini, walaupun agak terlambat; 